\title{
SELECTED CHARACTERISTICS OF THE WHOLEFOOD MARKET
}

\author{
H. Šenkeříková, J. Stehlíková, L. Špačková
}

Received: December 17, 2010

\begin{abstract}
ŠENKEŘÍKOVÁ, H., STEHLÍKOVÁ, J., ŠPAČKOVÁ, L.: Selected characteristics of the wholefood market. Acta univ. agric. et silvic. Mendel. Brun., 2011, LIX, No. 2, pp. 393-398

The paper deals with characteristics of branch with products of ecological agriculture in Czech Republic. Present state of crop and animal production on ecological farms is analyzed. Paper is also focused on analysing distribution channels of organic products.

To the most often manufactured organic products belong according to dominate activities of producers meat processing, producing bake, confectioner and other floury products (mainly fresh pastry), milk processing, production of dairy commodities and cheese and fruit and vegetables. In the last few years the number of wine manufacturer is rising. Second important category for development of market with organic products are distributors or subjects, who set afloat wholefood or organic products including import and export without whatever further processing.

In terms of marketed organic products and wholefood, sale of animal organic products dominates above crop. In terms of sharing main categories of ecologicaly cropped growns in the Czech Republic, the biggest share have legumes processed for corns and vegetables. The most important category in ecological agriculture in animal production is explicitly beef-raising.

In comparison with the end of 2008 number of wholefood producers increased up of 14 percents, which means retardation in comparison with the growth between the years 2007 and 2008. Leading position on the market with offered wholefood has the drug-store chain dm. It offered more than 488 organic products in September 2010. With a big distance Globus follows this drug-store chain with 341 organic products and then are all nets of hypermarkets.

According to the shares of particular suppliers dm drug-store market is found on the top, which supplies its shops with wholefood of german producer Alnatura. In the second place there is the company Pro-bio and in the third place is the supplier of infantile nutrition HiPP Czech.

One possibility for launching organic products into the market are very favorite so called suppliers' packets (in Czech Republic the term boxes is used). Consumers can order fresh fruit and vegetables directly by the producer on his web sites. The producer packs the packet according to the consumers' needs and he supplies it once a week to the consumer's home or to another address. The producers, who offer these supplier packets, supplement their offer of exotic fruits or products of their partner producers, for making their offer more attractive. The highest demand of boxes is in big cities. The paper is a part of solution of the research plan of FBE MENDELU in Brno, No. 6215648904.
\end{abstract}

ecological agriculture, bioproduct, farm

Ecological agriculture has a long tradition and history. Since the beginning of the last century some European thinkers supposed using chemistry and soil conditioner factitious and unnatural. On this ground the ecological farmer movement was established. It was spread all over the word (FOA, 2007).
Ecological agriculture is a modern form of land management without using chemical inputs with adverse effect on the environment and both human and animal health. This agricultural production system, which makes possible producing high-quality foodstuff, is an integral part of Czech agricultural policy. 
Except the production of wholefood, ecological agriculture contributes to better living conditions of livestock, environment protection and to increasing environmental biodiversity (MZE, eAGRI, 2010).

\section{METHODS AND RESOURCES}

The paper deals with characteristics of branch with products of ecological agriculture in the Czech Republic. Present state of crop and animal production on ecological farms is also analyzed in the paper, in comparison with conventional agriculture. It concerns acreage, the number of farms and production quantity. In excluded areas, the development of ecological agriculture in Czech Republic is also analyzed. The paper is also targeted to the analysis of distribution channels with wholefood.

The data is drawn on the Ecological agriculture in Czech republic yearbook, editted by Ministery of agriculture, and also on internet sources, named in literature overview. Gain data will be further processed by authors and used for findings creation.

Basic statistic methods and the method of comparation will be used.

\section{RESULTS AND DISCUSSION}

\section{Development of ecological agriculture in Czech Republic}

The total ecologically managed land area in December 31, 2009 is 398407 ha, which is 9.38 percent part on the farm land in the Czech Republic. Towards the end of the year 2009 over 8 percent of Czech agricultural businessmen farmed in ecological way. The average size of organic farm has decreased since the year 2001, when it achieved acreage of 333 ha. Developing the acreage of the whole area and other indicators can be seen in Tab. I. New farms with lower acreage join the system of ecological agriculture. We can also keep track of dividing present farms in smaller units in the framework of so-called young farmers. Despite of this trend, it is constantly true, that the acreage of an average organic farm is bigger than an average acreage of conventional farm. In 2009 the acreage of an average organic farm was 148 ha (MA, 2009).

The whole acreage of agricultural land used in ecological agriculture is increasing as well as the number of farms managing in this way. Annual

I: The development of total acreage in ecological farming and numbers of organic farms

\begin{tabular}{ccccc}
\hline Year & $\begin{array}{c}\text { Number of farms } \\
\text { managing in EA }\end{array}$ & $\begin{array}{c}\text { Annual change in } \\
\text { numbers of farms in EA } \\
\text { (percent) }\end{array}$ & Whole acreage in EA (ha) & $\begin{array}{c}\text { Share of EA on the whole } \\
\text { acreage of ASF (percent) }\end{array}$ \\
\hline 2000 & 563 & 19 & 165699 & 3.86 \\
2001 & 654 & 16.2 & 218114 & 5.09 \\
2002 & 721 & 10.2 & 235136 & 5.5 \\
2003 & 810 & 12.3 & 254995 & 5.97 \\
2004 & 836 & 3.2 & 263299 & 6.16 \\
2005 & 829 & -0.8 & 254982 & 5.98 \\
2006 & 963 & 16.2 & 281535 & 6.61 \\
2007 & 1318 & 36.9 & 312890 & 7.35 \\
2008 & 1946 & 47.6 & 341632 & 8.04 \\
2009 & 2689 & 38.2 & 398407 & 9.38 \\
\hline
\end{tabular}

Source: MA (data valid in 31 December of examined year), adjusted by authors

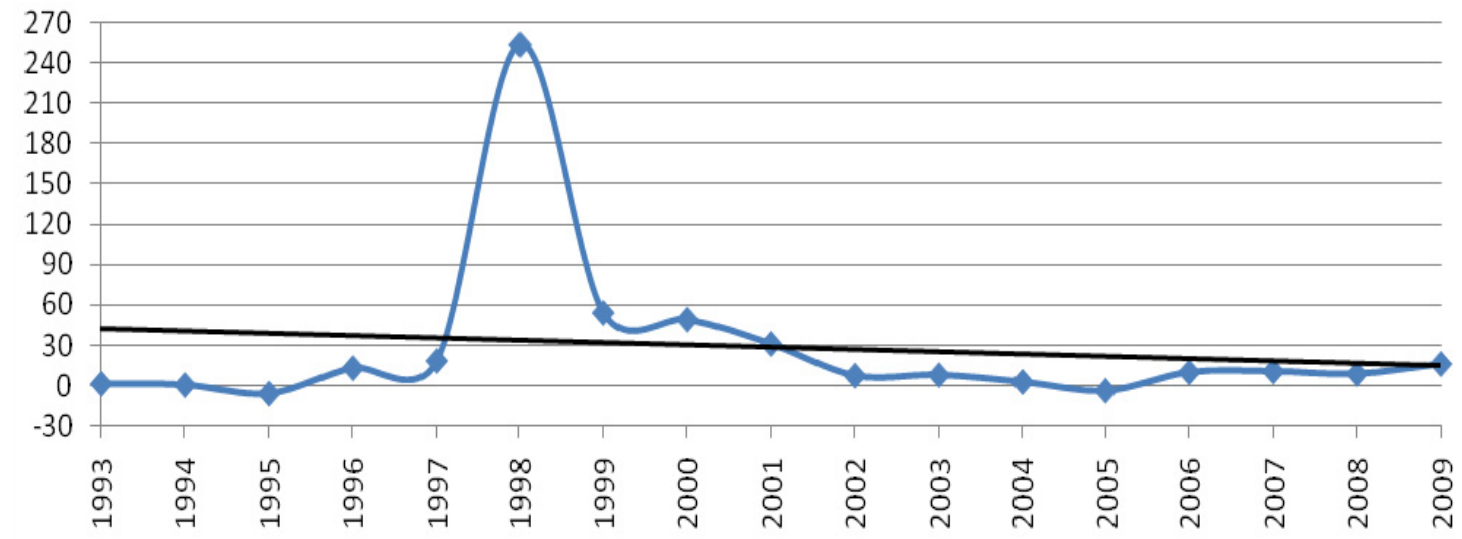

1: Interannual change in the total area of organic farming (percent)

Source: MA, adjusted by authors 
II: Structure, production and yield of products in organic farms in 2009

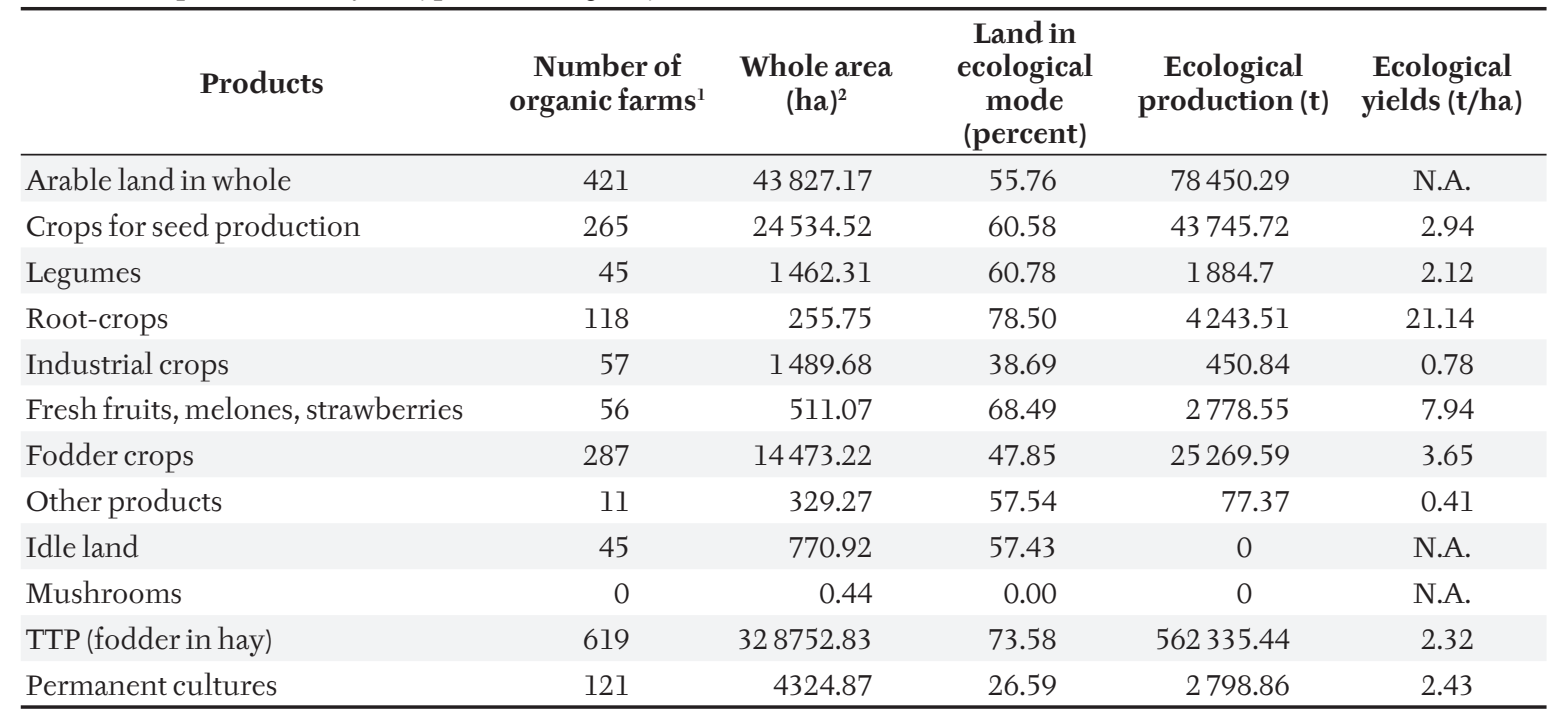

${ }^{1}$ Number of organic farms, which have products in ecological mode

${ }^{2}$ Covers the area ranked in ecological mode and in the period of conversion

Source: Statistic survey of UZEI 2009

change of whole acreage used by farmers managing in the system of ecological agriculture is illustrated in Fig. 1 and it embodies a decreasing tendency. This fact is caused by data comparison in a long time. This data are influenced by the „boom" of ecological agriculture, supported with the government policy in 1998. If we confronted the data in last 5 years, the annual acreage of ecological agriculture would have an increasing trend.

Organic farmers are managing on 450000 ha of agricultural land, which is more than 10 percent of the whole acreage of agricultural land in Czech Republic. During the year 2010 the number of ecological farmers increased by 805 subjects, which is the highest absolute growth since 1990. The acreage increased by 10000 ha and the number of organic farmers is higher by 146 additional manufacturers. In August 2010 farmed in Czech Republic 3500 organic farmers and more than 650 manufacturers attended the market with wholefood (Singr, 2010).

\section{Present conditions of crop production}

Main growns on arable land are cereals with sharing over 56 percent (the most frequent are oat and wheat) and fodder plants (share of 33 percent). Identically about 3.5 percent of arable land commandeer legumes (green pea makes 55 percent of these areas) and industrial crops (80 percent of their areas are made by oilseeds, which is especially mustard occupying more than a half of oilseeds' area; rape was dominant earlier). Vegetables is planted on less than 1.2 percent of arable land, whereas two thirds of its area is occupied by growth-vegetable, e.g. pumpkins (60 percent of the whole 511 ha is occupied by pumpkins). Small part of arable land (i.e. 0.58 percent) is nibbled by root crops, especially by potatoes (98 percent of root crops).
The extent of ecological production (i. e. procution only of the areas in ecological mode) achieved 643.5 thousands tones in 2009, production of fodders (recalculated on hay) makes 91 percent of the whole (i.e. 562.3 thousands tones of TTP and additional 25.3 thousands tones of fodders on arable land). The total production of arable land made 78450 tones, 56 percent of this area occupied crops and 32 percent fodders on arable land (volume in hay). In terms of crops, the highest production volume reach crops, which is the same as in the framework in area, wheat and oat (which make almost 40 percent of the whole crops production). An output of hectare is generally lower in EA than in conventional agriculture, but the comparison is difficult, because the yield differs not only between ecological and conventional farms, but also between ecological farms each other.

In main categories of ecologically grown products on the whole area in Czech Republic, the highest share have legumes and vegetables on a long-term basis (5.0 percent and 5.8 percent is in EA). Following are fodder crops with the share of 3.8 percent and almost 2 percent of crops areas are in EA. But if we compare the production volume, no main product category will reach 5 percent share of the whole production in the Czech Republic. The highest share have legumes, again, followed by vegetables (3.0 and 1.6 percent of the whole production in the Czech Republic). Annual increasing areas of arable land made 30 percent (let us say 36 percent for areas in ecological mode). The highest increase of areas in ecological mode was pursued in crops (increase in 46 percent) and fodder crops (in 27 percent). The TTP areas increased in 16 per cent and TK in 37 percent (MA, 2009). 


\section{Present conditions of animal production}

The structure of animal production is illustrated in TAB. III. Share of the whole animal stays in the Czech Republic shows, that the highest representation in EA has breeding sheep and goats (almost one third of sheep and quarter of goats breeding in the Czech Republic is kept in ecological way). Oxen and horses are kept in the share of 10 percent in this way, dairy cows only 0.65 percent of the total number. An important expansion can be seen by poultry-raising, especially by broilers. In 2008 poultryraising was implemented by 24 organic farms (only 3 of them were specialized in broilers), whereas in 2009 the number increased to 38 organic farms raising poultry and 9 raising broilers. In spite of the expressive increase, the state of poultry and pigs in EA of the whole number is only 0.2 percent. In breeding pigs was occurred a positive rise (to 26.8 percent), which also confirms the increase from 14 to 21 organic farms with breeding pigs. Other categories (except bees) marked decrease of the number of animals, the most remarkable was the number of dairy cows (to 50 percent) in 2614 pieces. Their share on the total amount of cost decreased firstly below 2 percents (MA, 2009).

In the aggregate in 2009 was produced 7266 tones of meat, but after the sheet of estimated meat quantity sold in alive state, the production decrease on 3300 tones. 90 percent of this number is beef. In conditions of diary production 13.2 mil. liters of milk were produced. 96 percent of this amount is cow's milk, but its production is stagnating. On the contrary, a big increased was marked by sheep's milk production and then by goat's cheese. The production of eggs rose to 24.8 percent while increasing the number of laying hens.

\section{Analysis of wholefood distribution channels}

Typical distribution channels, through them organic products get to the consumers, are:
- Local and specialized organic markets.

- Specialized shops in rural and municipal areas.

- Stalls around roads in rural areas.

- Sale directly from the farm, where is food produced in.

- Shopping through internet - home or end-user place's delivery - or so called „box system“ (European Commission, 2010).

In the last year, the trend of direct food distribution began to promote, but it is still little advanced and this year should come to its rise. Through direct launch into the market, strong linkages between rural organic farmers and municipal consumers are made (Singr, 2010).

In these days, growers must ponder, how much money and work can venture to invest by launching their products on the market. Each grower cannot lead his own shop and supplying bigger shops by goods goes with a lower profit. This is why many of them take advantage of possibilities, such as (Agronavigator, 2010):

Sale to restaurants and cafes: These clients require high-quality products. Growers should find out in advance, if they can satisfy these requirements. In case that the quality convinces customer's demands and it is able to supply the purchaser regularly, solid connection between consumer and supplier can be fastened, even with adequate prices.

Food service for institutions, such as school canteens, students' halls, nursery schools and retirements homes, is a possibility to sell fresh products in big amounts. If the product is established to the offer, it is easy to let final consumers know, that it is a local product, which comes from ecological agriculture. Depending up the support of policy and school system, public feeding can increase consummation of wholefood (good practice: Italy). It is easier to implement wholefood in schools, if the school alimentation is secured by law (e.g. in Italy). If

III: Number of animals on organic farms in the Czech Republic in 2008 and 2009

\begin{tabular}{lcrrr}
\hline \multirow{2}{*}{ Category of animals } & $\begin{array}{c}\text { Number of organic farms } \\
\text { in 31/12/2009 }\end{array}$ & $\begin{array}{c}\text { Number of ecologically breeded } \\
\text { animals }\end{array}$ & Annual change (percent) \\
\cline { 3 - 4 } & 286 & $\mathbf{2 0 0 8}$ & $\mathbf{2 0 0 9}$ & \\
\hline Horses & 826 & 151723 & 2982 & -22.97 \\
Oxen & 361 & 64559 & 53038 & -10.35 \\
Sheep & 132 & 5403 & 4352 & -17.85 \\
Goats & 21 & 1569 & 1990 & -19.45 \\
Pigs & 38 & 7427 & 25292 & 26.83 \\
Poultry & 2 & 100 & 88 & 240.54 \\
Rabbits & 13 & 56 & 48 & -12 \\
Other animals & 2 & 750 & 458 & -14.29 \\
Fish & 13 & -38.93 \\
\hline
\end{tabular}

1) The number of ecologically breeded animals comprises all animals in organic farms (it means not only certificated pieces according to the demand of organic farmers and then only animals after temporary period)

2) The category of other animals included in 20074 buffalos and 3 donkeys, in 2008 galloways and in 200918 galloways, 20 donkeys, 5 buffalos and 5 llamas.

Source: Statistical survey on organic farms UZEI 2008 and 2009 
IV: Animal production on ecological farms in 2008 and 2009

Production from ecological farms

Annual change (percent)

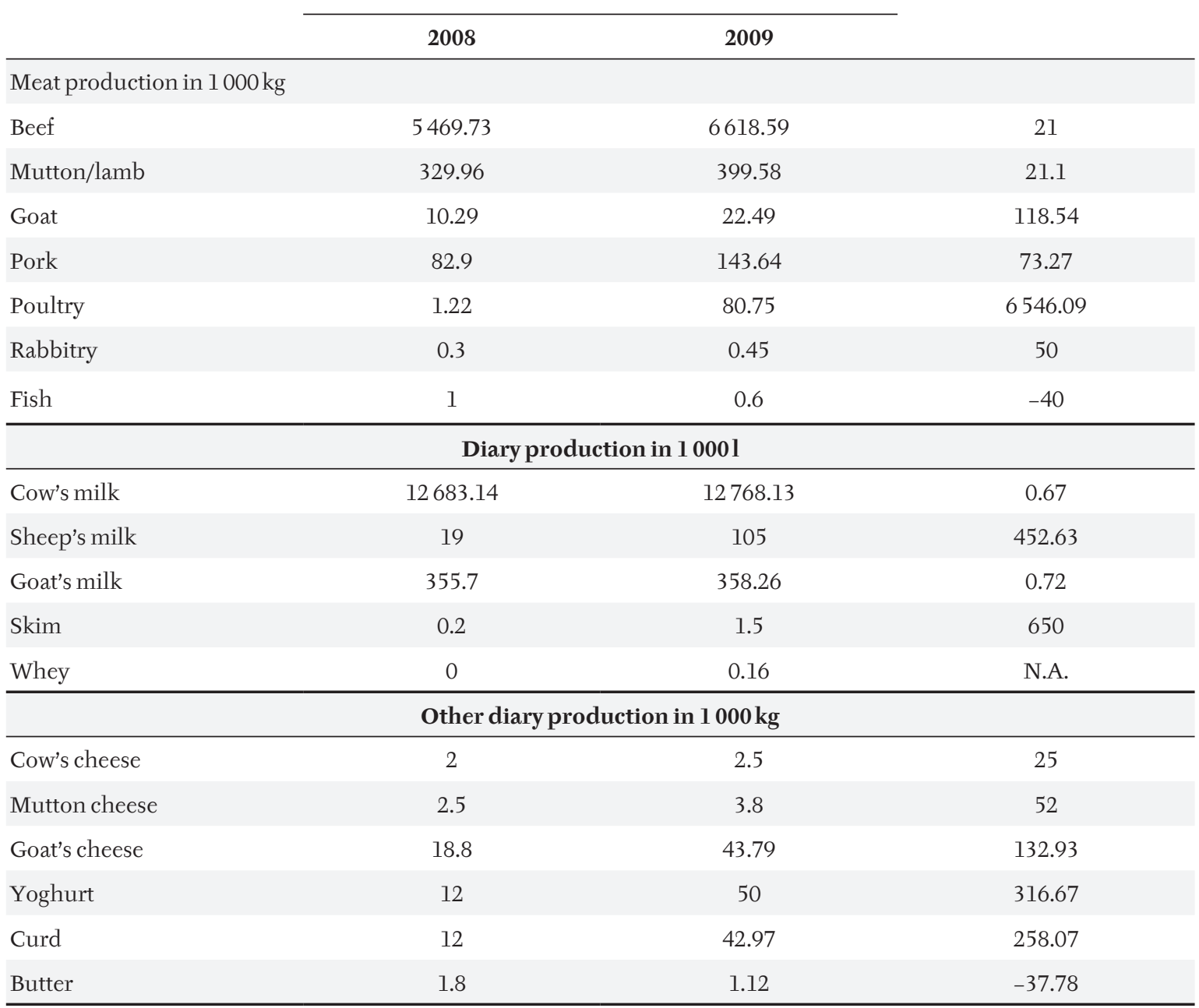

Source: Statistic survey UZEI 2008 a 2009

children bring snacks from homes or they go home to eat, it is more difficult.

Supplier packet (in the Czech Republic it is used the term „boxes“). Consumers can order fresh food and vegetables directly by the grower on his websites. In consequence, the grower packs the packet according to consumer's needs and he delivers it once a week to consumer's home or to another demanded place. Growers offering supplier packets replenish their proposal by exotic fruits or partner farmers' products, to make their offer more attractive.

Projects of one's own vegetables harvest, farmers hire their sown fields to consumers and they can consequently harvest for all the season. This offer can be easily combined with selling them other own products, for example meat. These projects can be found on suburb in Austria and Germany.

Self service counters. People, who offer products such as carrot, apples, potatoes or flowers, can situate their goods near the road in some rural areas as a self service counter. Necessary is a small, wellentrenched cash desk. This method does not come with a high profit, but it also does not demand much work. Very important is trust between suppliers and consumers.

Slot-machines. Cooling slot machines can be installed wherever in town centres. Slot machines has a similar use for many products. Milk, eggs or potatoes can be delivered by this machines. Customers use them in the same way as other slot-machines.

\section{Offer of wholefood in retail chains}

Leading position on the market with offered wholefood has the drug-store chain $\mathrm{dm}$. It offered more than 488 organic products in September 2010 (monthly decrease to 1 percent). With a big distance Globus follows this drug-store chain with 341 organic products (monthly increase to 1 percent) and then are all nets of hypermarkets: Interspar (319, +7 percent), Albert hypermarket (264, +6 percent), 
Tesco (235, -2 percent) and Kaufland (228, -1 percent). Supermarkets offer in comparison with hypermarkets a half of a total amount of organic products: Billa (162, -3 percent) and Albert supermarket (136, no change). In Žabka can customers buy up to 106 organic products, in Coop $(65,-3$ percent), and in discount trades - Penny Market $(58,-5$ percent). When we compare shares of suppliers, in the first place is dm drugstore, which delivers to its shops wholefood from the German producer Alnatura (380 products, +1 percent). In the second place there is the company Pro-bio (343 products, -1 percent), in the third place is the supplier of infantile nutrition HiPP Czech (255 products, -9 percent), the fourth is wholesale Country Life (226 products, +1 percent) (Bio-info, 2010).

\section{SUMMARY}

The total ecologically managed land area in December 31, 2009 is cca 400000 ha, which is 9.38 percent part on the farm land in the Czech Republic. In absolute number, it is the highest increase of acreage in the whole history of ecological agriculture. Similarly the increase of registered organic farmers rose in 2689 subjects (this is to 743), which is the highest growth since 1990.

Ministry of Agriculture supposes, that the share of wholefood will be in five years in 5 percent, whereas in present it is only 1 percent. At the same time (according to MA - Svět potravin, 2010) the proportion of exported and imported products will spin round, for the profit of Czech products.

The volume of ecological production on arable land rose annual to 17 percent. This increase was caused especially by the growth of corn production. It occuerd to a decrease by industrial crops and fodder crops.

In 2009 it was breeded in average 224 thousands pieces of animal on ecofarms (without beekeeping and fish). The most important category in EA is beef raising, followed by sheep raising.

In the framework of animal bioproduction it comes to a big increase in poultry produkction. Other categories also marked growth except fish meet, where the production decreased to 40 percent.

To the typical distribution channels of wholefood belong local and specialized biomarkets, specialized shops in rural and municipal areas, stalls around roads in rural places, selling directly from farms, where was the wholefood produced and buying on internet.

\section{REFERENCES}

AGRONAVIGATOR [online]. 2010: [cit. 2010-11-13]. Jaké možnosti nabízí přímé uvádění bioproduktů na trh? Available on www: <http://www.agronavigator.cz/ekozem/default.asp?ch=99\&typ=1\&val= 104970\&ids $=3228>$.

BIO-INFO [online]. 2010 [cit. 2010-10-21]. Aktuálnî vývoj nabídky biopotravin $\mathrm{v}$ maloobchodních řetězcích. Available on www: 〈http://www.bioinfo.cz/zpravy/aktualni-vyvoj-nabidky-biopotravin- $v$-maloobchodnich $>$.

DARMOVZALOVÁ, I. a kol., 2010: ÚZEI. Statistická šetření ekologického zeměděltství provedená v roce 2009. Available on www: <http://eagri.cz/ public/web/file/56451/Zprava_EZ_2009_aktualizovano_16._6._2010>.

eAGRI, internetový portál Ministerstva zemědělství [online]. 2009-2010 [cit. 2010-10-12]. Ekologické zemédèlství. Available on: <http://eagri.cz/public/ web/mze/zemedelstvi/ekologicke-zemedelstvi/> .

EVOPSKÁ KOMISE, 2010: Ekologické zemédèlství [online]. 2010 [cit. 2010-10-18]. Na trhu. Available on www: <http://ec.europa.eu/agriculture/organic/ organic-farming/what-organic/the-market_cs $>$.

FOA nadační fond pro ekologické zemědělství [online]. 2007: [cit. 2010-10-06]. Ekologické zemédèlství Available on www: < http://www.foa.cz/cs/ekologicke-zemedelstvi/>.

Ministerstvo zemědělství. Ročenka ekologické zemědělství v České republice. Praha: Ministerstvo zemédèlství, 2009. 44 s. Available from www: <http:// eagri.cz/public/web/file/67868/Rocenka_2009_ web_komplet.pdf $>$. ISBN 978-80-7084-927-9.

SINGR, M., Ekolist.cz [online]. 2010: [cit. 201010-14]. Mésíc biopotravin - trendem je nákup prímo od výrobce. Available on www: <http://ekolist.cz/ cz/zpravodajstvi/zpravy/biopotraviny-v-cr-jsoupro-spotrebitele-drahe-malokdo-nakupujeprimo-na-farmach $>$.

SVĚT POTRAVIN [online], 2010: [cit. 2010-10-19]. MZe: Ekofarem v ČR rekordně pribylo, je jich již témër 3500. Available on WWW: <http://www.svet-potravin.cz/clanek.aspx?id=2140\&idreturn $=0>$. 